\title{
Meer bewegen: doorverwijzing naar beweegactiviteiten door eerstelijnszorgverleners
}

\author{
Tessa M. Schurink-van 't Klooster · Anne Loyen · Karin I. Proper
}

Published online: 22 January 2020

(C) The Author(s) 2020

\begin{abstract}
Samenvatting Het belang van preventie in de zorg wordt steeds meer erkend. Het bevorderen van een gezonde leefstijl, waaronder meer bewegen, vormt hiervan een belangrijk onderdeel. Met dit onderzoek is inzicht verkregen in het doorverwijzen van eerstelijnszorgverleners naar beweegactiviteiten en de redenen voor het (niet) doorverwijzen van patiënten/cliënten naar beweegactiviteiten. In interviews zijn huisartsen, praktijkondersteuners, jeugdartsen en jeugdverpleegkundigen gevraagd naar redenen voor het wel/niet doorverwijzen naar beweegactiviteiten en de benodigdheden om (vaker) te verwijzen. Een online enquête onder dezelfde doelgroepen was opgezet om deze informatie te kwantificeren. Deelname aan de interviews $(n=25)$ en enquête $(n=100)$ was laag. De jeugdgezondheidszorg adviseert vaak om meer te bewegen, vooral bij kinderen met overgewicht. Huisartsen doen dat, in lijn met de kerntaken, in mindere mate en dan vooral wanneer het de klacht kan verhelpen waarvoor ze geconsulteerd worden. Eerstelijnszorgverleners verwijzen dus voornamelijk mensen met gezondheidsproblemen door en er is minder aandacht voor bewegen ten behoeve van primaire preventie. De belangrijkste redenen waarom eerstelijnszorgverleners niet doorverwijzen hangen samen met een beperkte motivatie, de financiële situatie van patiënten en gebrek aan tijd tijdens het consult. Om vaker door te verwijzen hebben zorgverleners behoefte aan een passend en betaalbaar beweegaanbod voor alle doelgroepen.
\end{abstract}

\footnotetext{
T. M. Schurink-van 't Klooster $(\bowtie) \cdot A$. Loyen · K. I. Proper Centrum voor Voeding, Preventie en Zorg, Rijksinstituut voor Volksgezondheid en Milieu (RIVM), Bilthoven, Nederland

tessa.schurink@rivm.nl
}

Trefwoorden bewegen doorverwijzing . eerstelijnszorg · preventie

\section{Physical activity: referral to physical activities by primary care providers}

Abstract The importance of prevention in healthcare has increasingly been recognized. The promotion of a healthy lifestyle, including physical activity, by primary healthcare providers is important in this. This study provides insight into the referral process of primary healthcare providers to physical activity and the reasons for (not) referring patients/clients to physical activities. In interviews, GPs, GP-based nurse specialists, pediatricians and pediatric nurses were asked for their reasons for (non-)referral to physical activity and their needs to refer (more often). An online survey among these target groups was set up to quan-

\section{Kernpunten}

- Vanuit de jeugdgezondheidszorg wordt vaak geadviseerd om meer te bewegen, vooral bij kinderen met overgewicht.

- Huisartsen verwijzen vooral door naar beweegactiviteiten wanneer deze de klacht kunnen verhelpen waarvoor patiënten op het spreekuur komen.

- Een beperkte motivatie van patiënten om meer te bewegen, de financiële situatie van de patiënt en gebrek aan tijd tijdens het consult zijn de belangrijkste redenen waarom artsen patiënten niet doorverwijzen naar bewegen.

- Er is behoefte aan een passend en betaalbaar beweegaanbod voor iedereen. 
tify this information. Participation in the interviews $(n=25)$ and survey $(n=100)$ was low. Pediatricians often recommend physical activity, especially in overweight children. In line with the core tasks of the GP, GPs mainly promote physical activity if it is related to the health complaint. So, primary healthcare providers mainly refer people to reduce the patients' health complaints. Main reasons why doctors do not advise to increase levels of physical activity are a limited motivation, the financial situation of the patients and lack of time during the consultation. An appropriate and affordable physical activity offer for everyone is needed to refer more often.

Keywords physical activity $\cdot$ referral $\cdot$ primary care · prevention

\section{Inleiding}

Bewegen is gezond voor alle leeftijdsgroepen. Voldoende bewegen bevordert de kwaliteit van leven en verlaagt het risico op het ontstaan van diverse chronische ziekten en aandoeningen, zoals hart- en vaatziekten, diabetes, osteoporose, bepaalde vormen van kanker en depressie [1]. Volgens de in 2017 uitgebrachte richtlijnen voor bewegen zouden volwassenen wekelijks minimaal 150 minuten matig of zwaar intensief moeten bewegen, verspreid over diverse dagen, en kinderen dagelijks minstens een uur. Daarnaast zouden volwassenen en kinderen respectievelijk minimaal twee en drie keer per week spier- en botversterkende activiteiten moeten doen [2]. Ook moet veel stilzitten worden voorkomen. In 2017 voldeed $47 \%$ van de Nederlanders van vier jaar en ouder aan de beweegrichtlijnen. Daarbij zijn verschillen te zien naar achtergrondkenmerken. Kinderen in de leeftijd van vier tot en met elf jaar $(56 \%)$ en hoger opgeleide volwassenen $(55 \%)$ voldeden het vaakst aan de beweegrichtlijnen [1,3].

De combinatie van de positieve gezondheidseffecten van bewegen enerzijds, en het percentage Nederlanders dat onvoldoende beweegt anderzijds, vraagt om het stimuleren van bewegen onder een groot deel van de bevolking. De eerstelijnsgezondheidszorg biedt hiervoor een geschikte setting. Dat past ook bij de toenemende aandacht voor het stimuleren van preventie in de zorg onder het motto 'voorkomen is beter dan genezen' [4-7]. De commissie Innovatie Zorgberoepen en Opleidingen stelde in 2015 dat de Nederlandse samenleving moet verschuiven van nazorg naar voorzorg (ontzorgen). Daarbij speelt preventie in het algemeen en lichamelijke beweging in het bijzonder een belangrijke rol. Hoewel huisartsen in eerder onderzoek hebben aangegeven van mening te zijn dat zij een rol hebben bij het stimuleren van meer bewegen bij hun patiënten, blijkt uit deze onderzoeken ook dat zij dit nog onvoldoende doen [8-10]. Uit eerder onderzoek bleek dat huisartsen hun patiënten voornamelijk stimuleren om meer te bewegen wanneer dit direct relevant is in het kader van de klacht van hun patiënten en dat dit geen routineprocedure is in het kader van primaire preventie [8-10]. Onderzoek laat echter wel zien dat huisartsen het in de loop van de tijd vaker met hun patiënt over levensstijl hebben [10].

De afgelopen jaren zijn verschillende samenwerkingsverbanden ontstaan tussen de zorg en beweegaanbieders [8]. Een bekend voorbeeld hiervan is de Beweegkuur [11]. Toch zijn vooral huisartsen nog weinig betrokken bij deze samenwerkingsverbanden [8]. Daarnaast is er sinds 2019 meer ruimte voor het doorverwijzen van patiënten naar beweegactiviteiten vanuit het basispakket van de zorgverzekering. Huisartsen kunnen mensen met een gezondheidsrisico door overgewicht verwijzen naar een van de zogenaamde gecombineerde leefstijlinterventies (GLI's), die erkend zijn door het Zorginstituut Nederland en het Centrum Gezond Leven van het RIVM. Zorggerelateerde kosten worden dan vergoed vanuit de basiszorgverzekering [12]. Huisartsen en andere eerstelijnszorgverleners kunnen mensen ook doorverwijzen naar andere vormen van bewegen, zoals een lokale sportclub, een buurtsportcoach of nationale en lokale beweegprogramma's. Beperkte kennis van lokale faciliteiten kan verwijzing (gedeeltelijk) belemmeren $[8,9]$. Het is belangrijk dat professionals die werkzaam zijn in de eerstelijnszorg goed zicht hebben op de mogelijkheden die er voor bewegen zijn en dat deze ook een plaats krijgen in de behandeling en richtlijnen.

Om een antwoord te krijgen op de vraag in hoeverre zowel volwassenen als kinderen in de eerstelijnsgezondheidszorg worden doorverwezen naar beweegactiviteiten als interventie en op de vraag naar welke vormen van beweegactiviteiten ze worden verwezen is onderzoek verricht naar het doorverwijzingsproces in de huisartsenpraktijk en jeugdgezondheidszorg. Tevens wordt gekeken naar in de redenen voor het al dan niet doorverwijzen naar beweegactiviteiten.

\section{Methode}

\section{Focus op huisartsenpraktijk en jeugdgezond- heidszorg}

De huisarts is vaak het eerste aanspreekpunt voor mensen met vragen over of problemen met gezondheid en ziekte, en vormt daarmee de spil in de eerstelijnszorg. De praktijkondersteuners (poh's) ondersteunen de huisarts op een aantal gebieden. Vanwege de spilfunctie van de huisartsenpraktijk in de eerstelijnszorg richt dit onderzoek zich op huisartsen en poh's, inclusief de poh geestelijke gezondheidszorg (poh-ggz). Voor jeugdigen van nul tot achttien jaar wordt deze functie (ook) vervuld door de jeugdgezondheidszorg. Daarom richt dit onderzoek zich ook op jeugdartsen en jeugdverpleegkundigen. Alle overige eerstelijnszorgverleners worden in dit onderzoek buiten beschouwing gelaten. 


\section{De uitvoering van het onderzoek}

Het onderzoek is uitgevoerd in 2018 en bestond uit twee delen: interviews en een enquête. Eerst zijn interviews uitgevoerd om een breed inzicht te krijgen in de redenen die eerstelijnszorgverleners hebben voor het al dan niet doorverwijzen naar beweegactiviteiten. Vervolgens is een enquête verspreid onder een grotere groep zorgverleners om te bepalen hoe vaak redenen voor het al dan niet doorverwijzen naar beweegactiviteiten benoemd worden voor verschillende doelgroepen. Het onderzoek is in 2018 uitgevoerd.

\section{De interviews}

In interviews zijn huisartsen, poh's, jeugdartsen en jeugdverpleegkundigen de volgende vragen gesteld: verwijst $\mathrm{u}$ wel eens naar bewegen? Op basis waarvan? Wie verwijst u naar bewegen? Om welke redenen verwijst $\mathrm{u}$ naar bewegen? Waar verwijst $\mathrm{u}$ naar door? En waarom? Op welke manier verwijst $u$ ? Wat zijn uw ervaringen met zo'n doorverwijzing? Om welke redenen verwijst $\mathrm{u}$ niet (altijd) door? Welke rol spelen de kosten/vergoedingen? En wat zou er nodig zijn om (vaker) te verwijzen? Deze vragen zijn zo breed mogelijk geformuleerd om volledig inzicht te kunnen verkrijgen. Nationale literatuur is doorzocht op input voor de formulering van de vragen.

De oproep voor jeugdartsen en jeugdverpleegkundigen is verspreid via verschillende kanalen, waaronder de ActiZ jeugdnieuwsbrief, GGD GHOR-nieuws, Facebook-groepen voor AJN-leden en -stafartsen, en V\&VN-leden. Poh's zijn geworven via een oproep op de Facebook-pagina en de website van de Nederlandse Vereniging voor Praktijkondersteuners (NVvPO). Huisartsen bleken moeilijk te bereiken en zijn daarom geworven via de coördinator van de NHG-Kaderopleiding Bewegingsapparaat. Om praktische redenen zijn tijdens een opleidingsdag twee focusgroepinterviews georganiseerd met huisartsen die deelnamen aan deze kaderopleiding. Aan deze focusgroepinterviews namen elf huisartsen deel. Daarnaast zijn nog twee huisartsen (buiten de kaderopleiding om) persoonlijk benaderd voor een individueel interview. In de focusgroepen zijn dezelfde vragen gesteld als in de individuele interviews. In de focusgroepinterviews konden de deelnemers tevens op elkaar reageren. De deelnemers kregen geen vergoeding.

De interviews zijn face-to-face afgenomen en duurden 15 tot 33 minuten. Twee interviews zijn door bereikbaarheidsproblemen telefonisch afgenomen; beide focusgroepinterviews duurden 45 minuten. De interviews waren semigestructureerd, waarbij gebruik is gemaakt van een leidraad. De interviews zijn opgenomen en woordelijk getranscribeerd. Op basis van de transcripten is een systematische analyse uitgevoerd met behulp van MaxQDA-software. Vooraf is er een codeboom met thema's opgesteld, die gedurende de analyses verder is aangevuld. Twee onderzoekers hebben ieder de helft van de transcripten gecodeerd. Vervolgens hebben zij de codering van de andere onderzoeker gecontroleerd. Alle discrepanties zijn besproken om consensus te bereiken. De codes zijn gecategoriseerd naar de volgende thema's: type verwijzing, redenen om te verwijzen, waarnaar wordt doorverwezen, manier van doorverwijzen, ervaringen met doorverwijzingen, redenen om niet door te verwijzen en benodigdheden om vaker door te verwijzen.

\section{De enquête}

Vervolgens is een online enquête afgenomen onder huisartsen, poh's, jeugdartsen en jeugdverpleegkundigen om te bepalen hoe vaak redenen voor het al dan niet doorverwijzen naar beweegactiviteiten voor verschillende doelgroepen genoemd worden. De resultaten van de interviews zijn gebruikt voor het opstellen van de vragen en antwoordmogelijkheden in de enquête. De vragen hadden betrekking op de frequentie van doorverwijzen, redenen om wel of niet door te verwijzen en het proces van doorverwijzing. De enquête was gericht op vier verschillende groepen patiënten/cliënten: 1) kinderen die niet voldoende bewegen maar zonder (een verhoogd risico op) leefstijlgerelateerde aandoeningen of psychische problemen (gezonde kinderen); 2) kinderen met (een verhoogd risico op) leefstijlgerelateerde aandoeningen of psychische problemen (risicokinderen); 3) volwassenen die niet voldoende bewegen maar zonder (een verhoogd risico op) leefstijlgerelateerde aandoeningen of psychische problemen (gezonde volwassenen); 4) volwassenen met (een verhoogd risico op) leefstijlgerelateerde aandoeningen of psychische problemen (risicovolwassenen).

Via het NIVEL-huisartsenregistratiebestand is een steekproef van 900 huisartsenpraktijken getrokken. Deze praktijken zijn via een brief uitgenodigd voor deelname. Poh's zijn geworven via een bericht op de website en de Facebook-pagina van de NVvPO en de website van de Landelijke Vereniging POH-GGZ. Jeugdartsen en jeugdverpleegkundigen zijn geworven via ActiZ (jeugdnieuwsbrief, website en twitter), GGD GHOR (nieuws), AJN (vergadering, Facebookgroepen), V\&VN (e-mail naar actieve leden) en NCJ (website, nieuwsberichten). De deelnemers kregen geen vergoeding.

\section{Resultaten}

\section{Deelname en kenmerken}

In totaal zijn er 25 eerstelijnszorgverleners geïnterviewd en hebben honderd eerstelijnszorgverleners de enquête ingevuld (tab. 1). In de enquête gaf $85 \%$ van de deelnemers aan op de hoogte te zijn van de nieuwe beweegrichtlijnen, en $68 \%$ rapporteerde hier zelf ook aan te voldoen. De deelnemers van de enquête hebben hun mening gegeven over drie stellin- 
Tabel 1 Aantal deelnemers aan de interviews en de enquête, naar beroepsgroep

\begin{tabular}{l|c|c|} 
& $\begin{array}{l}\text { Aantal (\%) deelnemers } \\
\text { interviews }\end{array}$ & $\begin{array}{l}\text { Aantal (\%) deelnemers } \\
\text { enquête }\end{array}$ \\
\hline $\begin{array}{l}\text { Huisartsen } \\
\begin{array}{l}\text { Praktijkonder- } \\
\text { steuners }\end{array}\end{array}$ & $13(52 \%)^{\mathrm{a}}$ & $35(35 \%)$ \\
\hline $\begin{array}{l}\text { Praktijkonder- } \\
\text { steuners-ggz }\end{array}$ & $0(0 \%)$ & $18(18 \%)$ \\
\hline $\begin{array}{l}\text { Jeugdartsen } \\
\begin{array}{l}\text { Jeugdverpleeg- } \\
\text { kundigen }\end{array}\end{array}$ & $4(16 \%)$ & $19(19 \%)$ \\
\hline \begin{tabular}{l} 
Totaal \\
\hline aElf door middel van focusgroepinterviews, twee individuele interviews
\end{tabular}
\end{tabular}

gen. De overgrote meerderheid (96\%) van de deelnemers was het (helemaal) eens met de stelling 'De eerstelijnszorgverlener heeft een rol in het stimuleren van lichamelijke activiteit.' De meeste zorgverleners (75\%) gaven daarnaast aan dat ze bekend zijn met het beweegaanbod in de buurt van de praktijk of instelling waar ze werken, en $71 \%$ waardeerde dit aanbod als kwalitatief goed.

\section{Redenen om te verwijzen}

Zowel jeugdartsen als jeugdverpleegkundigen gaven in de interviews aan dat zij eigenlijk in elk consult nagaan of het kind voldoende beweegt. Zoals een van de jeugdverpleegkundigen [man, 51 jaar] zei: 'In ons basis takenpakket zit het screenen van jongeren op gezond gedrag. Bewegen hoort daarbij.'

Genoemde redenen om kinderen te verwijzen naar bewegen waren het voorkomen of behandelen van overgewicht en de aanwezigheid van psychosociale aandoeningen of problemen, zoals depressie, ADHD of 'niet lekker in je vel zitten'. Andere redenen om te verwijzen waren het bevorderen van de motorische ontwikkeling, sociale contacten, schoolprestaties en vitamine D. Ook hoopten jeugdartsen en -verpleegkundigen dat kinderen plezier zouden beleven aan het sporten. Meer algemeen gaven jeugdartsen en -verpleegkundigen aan dat bewegen hoort bij een gezonde leefstijl, en goed is voor de algemene gezondheid.

In de huisartsenpraktijk wordt vooral door de poh's naar beweegactiviteiten doorverwezen. Zij zien voornamelijk volwassenen met diabetes, hart- en vaatziekten, en longaandoeningen. De meeste poh's stellen in elk consult vragen over het beweeggedrag van patiënten en benoemen het nut van bewegen. De huisartsen beginnen vooral over bewegen als dat gerelateerd is aan de klacht waar de patiënt mee komt. Zij verwijzen voornamelijk volwassenen en minder kinderen naar beweegactiviteiten. De redenen voor verwijzing die in de interviews genoemd werden hadden onder andere betrekking op de fitheid/gezondheid van de patiënt, het voorkomen/verminderen van medicijngebruik, het voorkomen/behandelen van psychische problemen, het voorkomen/behandelen van leefstijlgerelateerde aandoeningen en het bevorderen van sociale contacten. Over de sociale contacten zei een poh [vrouw, 52 jaar]: 'Soms is het doel ook om ze alleen maar naar buiten te krijgen. Soms zitten mensen alleen maar binnen de hele dag, dan is bewegen ook onder de mensen komen.'

Uit de enquête bleek dat 23 van de 28 jeugdartsen en -verpleegkundigen gezonde kinderen 'soms' of 'meestal' doorverwijzen (fig. 1). Negenentwintig van 35 huisartsen verwijzen gezonde kinderen 'nooit' of 'soms' door naar bewegen. Risicokinderen worden door elf van de veertien jeugdartsen 'altijd' of 'meestal' doorverwezen naar beweegactiviteiten. De veertien jeugdverpleegkundigen doen dit 'altijd', 'meestal' of 'soms', en 25 van de 35 huisartsen doen dit 'meestal' of 'soms'. In tab. 2 staan de belangrijkste redenen waarom eerstelijnszorgverleners kinderen doorverwijzen naar beweegactiviteiten. Bij gezonde kinderen en risicokinderen worden grotendeels dezelfde onderwerpen genoemd.

Gezonde volwassenen worden door 32 van de 35 huisartsen 'soms' of 'meestal' verwezen naar beweegactiviteiten (fig. 1). Tweeëntwintig van de 37 poh's en poh's-ggz doen dit 'meestal'. Risicovolwassenen worden door 23 van de 35 huisartsen en door 19 van de 37 poh's (inclusief poh's-ggz) 'meestal' doorverwezen naar bewegen. Ook bij gezonde volwassenen en risicovolwassenen worden grotendeels dezelfde redenen genoemd waarom ze worden doorverwezen naar beweegactiviteiten (tab. 2).

\section{Waar wordt naar doorverwezen?}

Geïnterviewde jeugdartsen en -verpleegkundigen verwijzen kinderen door naar verschillende vormen van bewegen, waaronder zelfstandig bewegen (buiten spelen, fietsen, naar school lopen), het reguliere beweegaanbod (sportlessen of een voetbalvereniging), laagdrempelig aanbod (waarbij kinderen bijvoorbeeld kennismaken met verschillende sporten), bewegen onder begeleiding van een fysiotherapeut en buurtsportcoaches. Ook verwezen sommigen naar gecombineerde leefstijlinterventies (GLI), maar was niet iedereen op de hoogte van dit soort programma's. Voor zelfstandig bewegen of het reguliere beweegaanbod wordt een algemeen ('buitenspelen') of een gericht ('voetballen bij de voetbalvereniging') advies gegeven. In dat laatste geval kunnen de contactgegevens van de beweegaanbieder (bijvoorbeeld de website) worden meegegeven. Voor andere vormen van bewegen, zoals fysiotherapie, een buurtsportcoach of beweegprogramma's, wordt vaker een echte doorverwijzing gedaan, waarbij het ook voorkomt dat de jeugdarts of -verpleegkundige contact opneemt en/of de kinderen aanmeldt.

Geïnterviewde huisartsen en poh's verwijzen naar het hele scala aan beweegaanbieders, van zelfstandige activiteiten (wandelen, fietsen, hardlopen) tot 

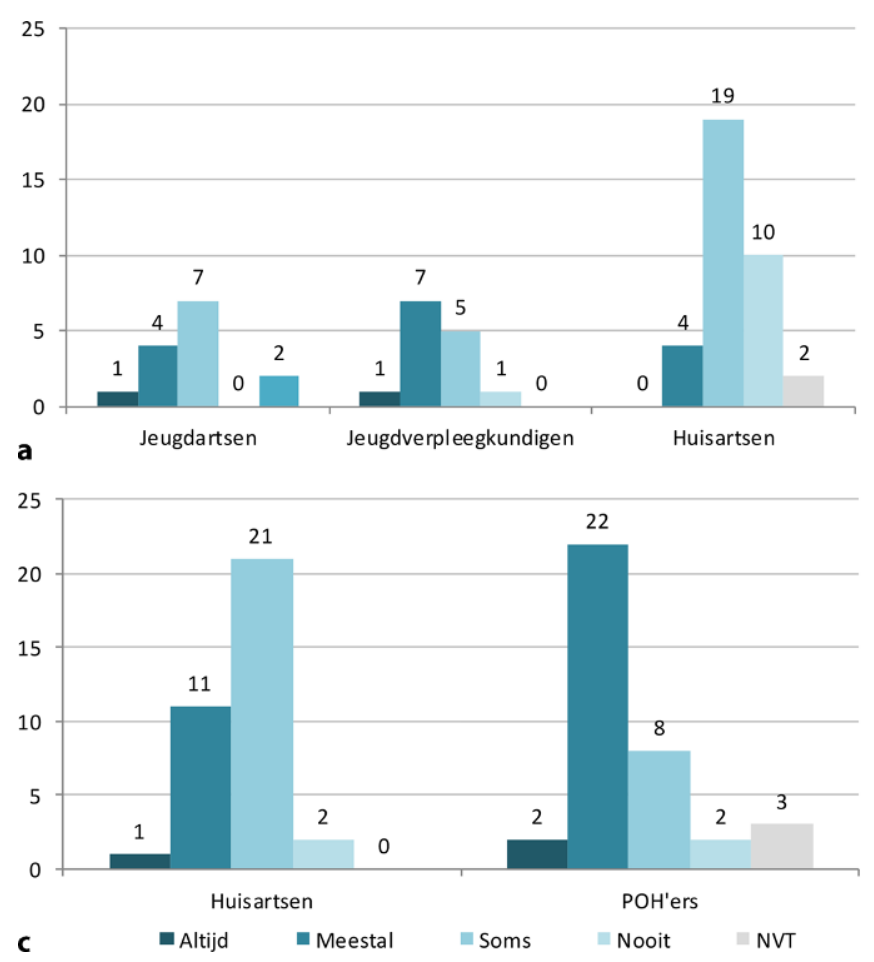

Figuur 1 Doorverwijzing door eerstelijnszorgverleners van gezonde en risico kinderen en volwassenen naar bewegen (enquête). a Gezonde kinderen = kinderen die niet voldoende bewegen maar zonder (een verhoogd risico op) leefstijlgerelateerde aandoeningen of psychische problemen. b Risicokinderen $=$ kinderen met (een verhoogd risico op) leefstijlge-

gecombineerde leefstijlinterventies. De buurtsportcoach was niet bij iedereen bekend. Adviezen van huisartsen en poh's voor zelfstandig bewegen of het reguliere beweegaanbod hadden vooral betrekking op de keuze van activiteiten die patiënten zelf leuk vinden. Daarnaast had een aantal huisartsen en poh's contacten met een of enkele beweegaanbieders naar wie zij voornamelijk verwezen. Sommige huisartsen en poh's gaven patiënten in het geval van een gericht advies een telefoonnummer, website of folder van de beweegaanbieder mee. Naar meer gespecialiseerde beweegaanbieders (fysiotherapeut, buurtsportcoach, gecombineerde leefstijlinterventie) wordt vaak 'echt' verwezen, bijvoorbeeld door middel van een verwijsbrief.

Uit de enquête bleek dat zowel kinderen als volwassenen het vaakst een algemeen advies krijgen om meer te bewegen (tab. 2), gevolgd door een verwijzing naar het reguliere beweegaanbod of de fysiotherapeut. Daarnaast worden volwassenen geregeld verwezen naar een eigen activiteit van de zorgverlener, bijvoorbeeld een wandelgroep.

\section{Redenen om niet te verwijzen}

Jeugdartsen en -verpleegkundigen vonden dat de financiële situatie van het gezin een belangrijke reden is om niet te verwijzen. Een gebrek aan financiële
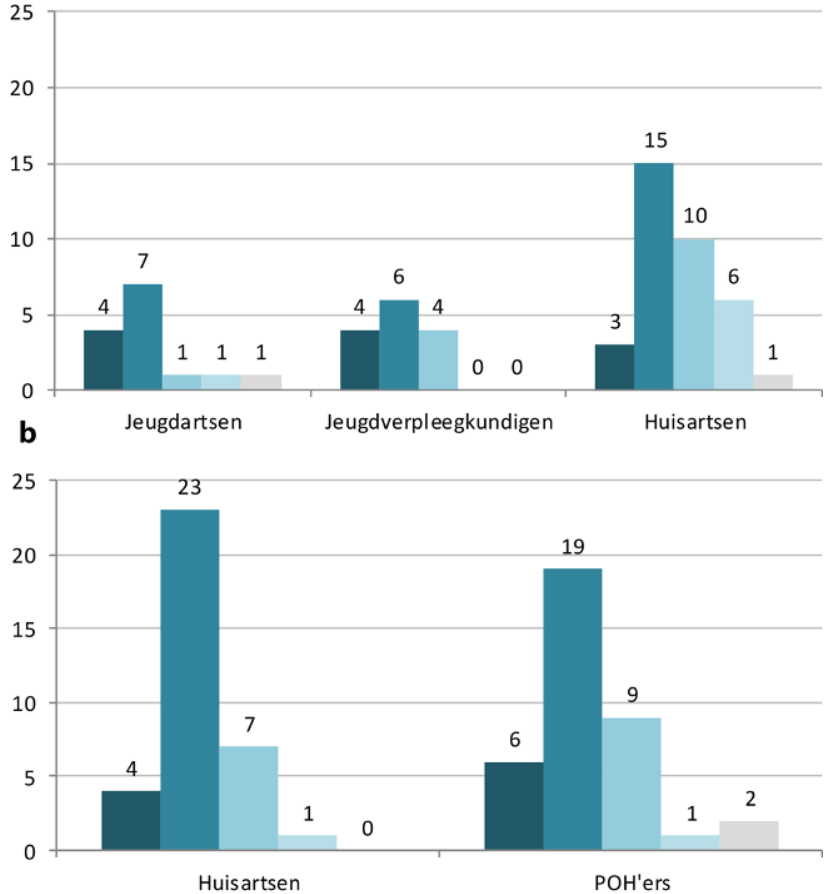

\section{d}

relateerde aandoeningen of psychische problemen. c Gezonde volwassenen = volwassenen die niet voldoende bewegen maar zonder (een verhoogd risico op) leefstijlgerelateerde aandoeningen of psychische problemen. d Risicovolwassenen $=$ volwassenen met (een verhoogd risico op) leefstijlgerelateerde aandoeningen of psychische problemen

middelen kan ervoor zorgen dat kinderen niet sporten, hoewel de meesten ook opmerkten dat er financiële ondersteuning kan worden aangevraagd bij (bijvoorbeeld) het Jeugdsportfonds. Daarnaast werd gebrek aan tijd tijdens het consult als reden genoemd om niet door te verwijzen naar beweegactiviteiten. In die beperkte tijd worden er prioriteiten gesteld, waardoor het kan voorkomen dat bewegen minder aandacht krijgt. Zoals een jeugdverpleegkundige [vrouw, 61 jaar] stelde: 'Ik moet binnen een korte tijd een waslijst aan dingen behandelen. Dus dan is het ook voorrang geven aan datgene wat haalbaar is. Of wat nóg belangrijker is.'

Ook de motivatie van de ouders werd genoemd als belemmerende factor voor doorverwijzing. Sommige ouders geven bijvoorbeeld aan dat zij het te druk hebben om hun kind naar sportactiviteiten te brengen, dat ze geen vervoer hebben of dat de sportclub te ver weg is. Tot slot vond een aantal jeugdartsen en -verpleegkundigen dat het moeilijk is om geschikte beweegaanbieders te vinden voor bepaalde doelgroepen, zoals heel jonge kinderen en migrantenkinderen.

In de huisartsenpraktijk kwam tijdens de interviews naar voren dat de motivatie van de patiënt een reden was om niet door te verwijzen naar beweegactiviteiten. Zoals een poh [vrouw, 52 jaar] het verwoordde: 'Je kunt natuurlijk niet doorverwijzen als ze dat zelf 
Tabel 2 Redenen van eerstelijnszorgverleners om gezonde en risicokinderen en volwassenen wel en niet door te verwijzen naar beweegactiviteiten; en naar welk beweegaanbod wordt verwezen (enquête)

\begin{tabular}{|c|c|c|c|}
\hline & $\begin{array}{l}\text { Redenen om } \\
\text { wel te verwijzen naar bewegen }{ }^{\text {a }}\end{array}$ & $\begin{array}{l}\text { Naar welk beweegaanbod wordt } \\
\text { verwezen }\end{array}$ & $\begin{array}{l}\text { Redenen om } \\
\text { niet te verwijzen naar bewegen }{ }^{\text {a }}\end{array}$ \\
\hline Gezonde kinderen ${ }^{b}$ & $\begin{array}{l}\text { Motorische ontwikkeling }(n=31) \\
\text { Leefstijl }(n=29) \\
\text { Algeheel welzijn }(n=29) \\
\text { Algemene gezondheid }(n=28) \\
\text { Sociale ontwikkeling }(n=25)\end{array}$ & $\begin{array}{l}\text { Algemeen advies }(n=43) \\
\text { Regulier beweegaanbod }(n=25) \\
\text { Fysiotherapeut }(n=12)\end{array}$ & $\begin{array}{l}\text { Gebrek tijd consult }(n=25) \\
\text { Financiële situatie gezin }(n=20) \\
\text { 'Ik denk er niet aan' }(n=19) \\
\text { Geen problemen }(n=16) \\
\text { Motivatie patiënt/cliënt }(n=15) \\
\text { Grotere problemen }(n=14)\end{array}$ \\
\hline Risicokinderenc & $\begin{array}{l}\text { Leefstijl }(n=41) \\
\text { Motorische ontwikkeling }(n=34) \\
\text { Algemene gezondheid }(n=34) \\
\text { Klacht verhelpen }(n=32) \\
\text { Algeheel welzijn }(n=31) \\
\text { Sociale ontwikkeling }(n=31)\end{array}$ & $\begin{array}{l}\text { Algemeen advies }(n=40) \\
\text { Regulier beweegaanbod }(n=34) \\
\text { Fysiotherapeut }(n=27)\end{array}$ & $\begin{array}{l}\text { Motivatie patiënt/cliënt }(n=29) \\
\text { Grotere problemen }(n=20) \\
\text { Financiële situatie gezin }(n=18) \\
\text { Gebrek tijd consult }(n=17)\end{array}$ \\
\hline $\begin{array}{l}\text { Gezonde } \\
\text { volwassenen }^{d}\end{array}$ & $\begin{array}{l}\text { Mobiliteit ( } n=45) \\
\text { Algemene gezondheid ( } n=43) \\
\text { Leefstijl }(n \text { 43) } \\
\text { Algeheel welzijn }(n=39) \\
\text { Klacht verhelpen }(n=38)\end{array}$ & $\begin{array}{l}\text { Algemeen advies }(n=61) \\
\text { Regulier beweegaanbod }(n=44) \\
\text { Fysiotherapeut }(n=31) \\
\text { Eigen activiteiten }(n=26)\end{array}$ & $\begin{array}{l}\text { Motivatie patiënt }(n=35) \\
\text { Financiële situatie patiënt }(n=28) \\
\text { Gebrek tijd consult }(n=21) \\
\text { Grotere problemen }(n=19) \\
\text { Gezondheid patiënt }(n=18)\end{array}$ \\
\hline Risicovolwassenen ${ }^{e}$ & $\begin{array}{l}\text { Mobiliteit }(n=53) \\
\text { Leefstijl }(n=52) \\
\text { Klacht verhelpen }(n=51) \\
\text { Algemene gezondheid }(n=46) \\
\text { Psychische problemen }(n=43)\end{array}$ & $\begin{array}{l}\text { Algemeen advies ( } n=61) \\
\text { Regulier beweegaanbod ( } n=49) \\
\text { Fysiotherapeut }(n=47) \\
\text { Eigen activiteiten }(n=27)\end{array}$ & $\begin{array}{l}\text { Motivatie patiënt }(n=39) \\
\text { Financiële situatie patiënt }(n=30) \\
\text { Grotere problemen }(n=26) \\
\text { Gezondheid patiënt }(n=19) \\
\text { Gebrek tijd consult }(n=18)\end{array}$ \\
\hline \multicolumn{4}{|c|}{$\begin{array}{l}{ }^{a} \text { Alleen de meest genoemde onderwerpen worden getoond, gerangschikt naar hoe vaak zij zijn genoemd } \\
\text { b Gezonde kinderen = kinderen die niet voldoende bewegen maar zonder (een verhoogd risico op) leefstijlgerelateerde aandoeningen of psychische problemen } \\
\text { c Risicokinderen = kinderen met (een verhoogd risico op) leefstijlgerelateerde aandoeningen of psychische problemen } \\
\text { d Gezonde volwassenen = volwassenen die niet voldoende bewegen maar zonder (een verhoogd risico op) leefstijlgerelateerde aandoeningen of psychische } \\
\text { problemen } \\
\text { e Risicovolwassenen = volwassenen met (een verhoogd risico op) leefstijlgerelateerde aandoeningen of psychische problemen }\end{array}$} \\
\hline
\end{tabular}

niet willen. Het grootste gedeelte geeft gewoon aan dat ze dat niet willen.'

Daarnaast werd ook de financiële situatie van de patiënt genoemd als belemmerende factor om te verwijzen naar beweegactiviteiten. Toch gaven veel huisartsen en poh's aan dat er ook beweegmogelijkheden zijn die weinig geld kosten (bijvoorbeeld wandelen) en dat het soms meer een kwestie is dat mensen het geld er niet voor over hebben. Over het beschikbare beweegaanbod waren ze over het algemeen tevreden, maar het aanbod is voor bepaalde doelgroepen beperkt, zoals mensen met een aandoening of beperking, ouderen en mensen die geen/weinig Nederlands spreken.

In de enquête was de meest genoemde reden om bij gezonde kinderen niet te verwijzen het gebrek aan tijd in een consult. Voor risicokinderen was dit de motivatie van het kind of ouders (tab. 2). Ook bij gezonde volwassenen en risicovolwassenen was de motivatie van de patiënt de meest genoemde reden om niet door te verwijzen (tab. 2).

\section{Wat is er nodig?}

Jeugdartsen en jeugdverpleegkundigen gaven geen eenduidig antwoord op de vraag wat er nodig is om kinderen (vaker) naar beweegactiviteiten te verwijzen. Het organiseren van een passend beweegaanbod voor alle kinderen en het vergoeden van sporten en fysiotherapie werden meermaals genoemd als bevor- derende factoren. Daarnaast uitten de jeugdartsen en -verpleegkundigen tijdens de interviews hun zorgen over de trend dat veel scholen niet meer gaan schoolzwemmen en dat er ook steeds minder gymnastieklessen worden gegeven. In de woorden van een jeugdverpleegkundige [man, 51 jaar]: 'Ik vind het persoonlijk heel jammer dat het schoolzwemmen haast niet meer bestaat. En dat het gymmen steeds moeilijker wordt. Wij zien in ons dagelijks werk dat jongeren een steeds moeilijkere motoriek hebben, omdat er gewoon minder bewogen wordt.'

Huisartsen en poh's noemden verschillende factoren die doorverwijzen naar beweegactiviteiten zouden kunnen bevorderen. In een aantal interviews kwam naar voren dat het goed zou zijn als er beweegvoorzieningen zijn waar mensen met een beperking of aandoening onder begeleiding en tegen een kleine vergoeding kunnen (blijven) bewegen. Tot slot vond een aantal huisartsen en poh's dat er méér nodig is dan alleen een verwijzing vanuit de huisarts om mensen gezonder te laten leven en dat er veel meer factoren meespelen. Zoals een huisarts [man, 40 jaar] zei: 'Natuurlijk, er ligt bij de huisartsen een grote preventietaak om voorlichting te geven en aan te geven wat gezond gedrag is. Maar als mijn patiënten bij mij weglopen en ze komen bij de Albert Heijn waar de pakjes sigaretten achter de balie liggen, waar ze drank kunnen kopen en waar kinderen allemaal snoep zien, hele schappen vol ... Ik denk dat daar een overheidstaak ligt.' 


\section{Beschouwing}

Met dit onderzoek is beter inzicht verkregen in de mate waarin volwassenen en kinderen in de eerstelijnsgezondheidszorg worden doorverwezen naar beweegactiviteiten als interventie, de redenen om dit al dan niet te doen en naar welke vormen van bewegen wordt verwezen. Jeugdartsen, jeugdverpleegkundigen en poh's blijken bewegen vaak tijdens het consult te bespreken, terwijl huisartsen dit hoofdzakelijk doen als het gerelateerd is aan de klacht van de patiënt. Risicokinderen en risicovolwassenen worden vaker verwezen naar beweegactiviteiten dan gezonde kinderen of volwassenen. Hieruit blijkt dat de inzet van beweegactiviteiten ter voorkoming van gezondheidsproblemen op dit moment in de eerstelijnszorg beperkt is, vooral onder huisartsen. Dat laatste is echter niet verrassend, omdat primaire preventie geen onderdeel uitmaakt van de vernieuwde kerntaken binnen de huisartsgeneeskunde zoals die begin 2019 zijn gepresenteerd [13]. Preventieve zorg voor patiënten met beginnende gezondheidsklachten of om complicaties te voorkómen (geïndiceerde zorg, respectievelijk zorggerelateerde preventie) is wel onderdeel van deze kerntaken. Resultaten van dit onderzoek bevestigen dit: huisartsen geven vooral beweegadvies als het gerelateerd is aan de gezondheidsklacht.

Ondanks de gedefinieerde taken van de huisarts is het van belang in kaart te brengen in hoeverre huisartsen, poh's, jeugdartsen en jeugdverpleegkundigen bewegen willen stimuleren onder patiënten met een verhoogd gezondheidsrisico of met gezondheidsproblemen. In het kader van de wens om preventie in de zorg te borgen [4-7], is het van belang hier meer zicht op te krijgen. Daarnaast werd er tijdens bijna alle interviews gesproken over bredere maatschappelijke/ politieke ontwikkelingen met betrekking tot bewegen en leefstijl. Zo hebben veel zorgverleners hun zorgen geuit over het beperkte beweegaanbod (schoolzwemmen, gymnastieklessen) op school, waardoor kinderen niet alleen minder beweging krijgen, maar bewegen ook een minder vanzelfsprekend onderdeel van hun leven wordt. Daarnaast werd vaak gezegd dat een doorverwijzing naar beweegactiviteiten niet in verhouding staat tot het beschikbare aanbod van bijvoorbeeld ongezond eten en drinken. Veel zorgverleners gaven aan dat deze factoren minstens zo belangrijk zijn om mensen gezonder te laten leven.

De belangrijkste redenen om niet te verwijzen zijn de motivatie van de patiënt/cliënt (of diens ouders), de financiële situatie van de patiënt/cliënt, een gebrek aan tijd tijdens het consult en de aanwezigheid van grotere/belangrijkere problemen. Deze bevindingen komen grotendeels overeen met die van eerder onderzoek van het NIVEL, waarin huisartsen (en fysiotherapeuten) ook werden gevraagd naar hun redenen om patiënten geen beweegadviezen te geven $[8,9]$. Ook in een ander recent onderzoek naar het doorverwijzingsproces van huisartsen naar leefstijlin- terventies bleek gebrek aan motivatie van de patiënt een belangrijke rol te spelen [14]. Hieruit blijkt dat volgens huisartsen de meeste van de redenen om niet te verwijzen bij de patiënt liggen. In dit onderzoek is de door de huisarts ingeschatte motivatie van de patiënten niet expliciet uitgevraagd. Dat wil zeggen dat we niet weten of huisartsen dénken dat patiënten niet gemotiveerd zijn en daarom niet beginnen over bewegen, of dat patiënten zélf aangeven dat zij niet gemotiveerd zijn als huisartsen over bewegen beginnen. Dit is iets waar vervolgonderzoek meer aandacht aan zou kunnen besteden. Het gebrek aan tijd tijdens het consult heeft te maken met de organisatie van de zorg. In dit kader gaf een aantal jeugdartsen en -verpleegkundigen aan dat er tijdens één consult veel onderwerpen moeten worden behandeld, waardoor ze moeten prioriteren. Een aantal zorgverleners zei daarover dat het juist veel tijd kost om (ongemotiveerde) patiënten/cliënten te motiveren om meer te gaan bewegen.

Er bestaan veel nationale en lokale beweeginitiatieven waar eerstelijnszorgverleners mensen naar kunnen doorverwijzen. In een eerder uitgebracht rapport is een onderverdeling gemaakt in zes vormen: 1) het reguliere beweegaanbod; 2) het laagdrempelige beweegaanbod; 3) een fysiotherapeut; 4) een beweegmakelaar; 5) een gecombineerde leefstijlinterventie; en 6) eigen beweegactiviteiten [15]. Om goed te kunnen adviseren en verwijzen is het voor zorgprofessionals belangrijk om op de hoogte te zijn van het beweegaanbod in de buurt. De zorgverleners die aan dit onderzoek deelnamen waren over het algemeen tevreden met het beschikbare beweegaanbod. Uit de interviews kwam echter naar voren dat het lastig kan zijn om voor bepaalde doelgroepen een geschikte activiteit te vinden, zoals jonge kinderen, kinderen en volwassenen die geen/weinig Nederlands spreken, kinderen en volwassenen met een aandoening of beperking, en ouderen. Hoewel een buurtsportcoach zorgverleners zou kunnen helpen bij het vinden of organiseren van beweegaanbod voor deze groepen, wisten lang niet alle eerstelijnszorgverleners in dit onderzoek de buurtsportcoach te vinden, en ook als dat wel het geval was, verwezen ze er niet vaak naar door. Dit blijkt ook uit eerder onderzoek naar de rol van buurtsportcoaches [16].

Of een doorverwijzing vanuit de eerstelijnszorg ook daadwerkelijk succesvol is hangt volgens het Mulier Instituut af van vijf belangrijke momenten [17]: 1) de overweging van de zorgverlener om iemand wel of niet door te verwijzen; 2) het intakegesprek; 3) de eerste sessie van de beweeginterventie; 4) het afronden van de interventie; en 5) het wel of niet doorgaan met bewegen na afloop van de interventie. Als er in de communicatie iets fout gaat, deelnemers drempels ervaren of de samenwerking tussen de betrokken partners niet goed is, kan het doorverwijzingsproces stokken. Voor een succesvolle doorverwijzing is het daarom belangrijk dat er een goede verbinding en terugkoppeling is 
tussen het zorg- en het beweegdomein, en om goed te luisteren en vragen te stellen tijdens het intakegesprek. Dit proces zal ook verbeteren wanneer er tijdens de opleiding van zorgprofessionals meer aandacht wordt besteed aan een gezonde leefstijl.

Een beperking van het onderzoek was de werving van huisartsen voor de interviews. Omdat de beroepsverenigingen bij de werving geen actieve rol vervulden, kon in deze groep niet breed worden geworven. Huisartsen zijn daarom geworven via de coördinator van de NHG-Kaderopleiding Bewegingsapparaat. Daardoor heeft een selectie van huisartsen aan de interviews deelgenomen die bewegen al belangrijk vindt. Door deze afwijkende manier van werven kunnen de resultaten van de interviews een positiever beeld geven dan die van de enquête, die dichter bij de werkelijkheid zullen staan. Om ook de resultaten van de enquête in context te plaatsen moet men bedenken dat het doel van de enquête was om de inzichten uit de interviews te kwantificeren. In samenwerking met de beroepsorganisaties is breed geworven via verschillende kanalen, waardoor een groot deel van de zorgverleners de oproep voor de enquête kan hebben gezien. Toch heeft slechts een klein deel van deze zorgverleners deelgenomen aan de enquête (14 tot 35 per doelgroep). Mogelijk omvat dit een selectie van zorgprofessionals die bewegen bovengemiddeld belangrijk vindt; $68 \%$ geeft namelijk aan dat ze zelf ook aan de beweegrichtlijn voldoen. De resultaten zijn daardoor niet representatief en moeten met de nodige voorzichtigheid worden geïnterpreteerd. Vanwege de selectieve respons bij de enquête kunnen de gepresenteerde resultaten een overschatting van de werkelijkheid zijn. Wel geven de resultaten van de enquête inzicht in de redenen die eerstelijnszorgverleners kunnen hebben om al dan niet door te verwijzen naar beweegactiviteiten. Dat zelfs zorgverleners die over het algemeen gemotiveerd zijn om patiënten te stimuleren meer te bewegen, barrières ondervinden bij het doorverwijzen en dat daarom niet altijd doen, laat zien dat het een complex probleem is.

\section{Conclusie}

Eerstelijnszorgverleners verwijzen voornamelijk mensen met gezondheidsproblemen door, er is minder aandacht voor bewegen ten behoeve van primaire preventie. Eerstelijnszorgverleners hebben behoefte aan een passend en betaalbaar beweegaanbod voor alle doelgroepen om hun patiënten/cliënten naartoe te verwijzen.

Open Access This article is licensed under a Creative Commons Attribution 4.0 International License, which permits use, sharing, adaptation, distribution and reproduction in any medium or format, as long as you give appropriate credit to the original author(s) and the source, provide a link to the Creative Commons licence, and indicate if changes were made. The images or other third party material in this article are included in the article's Creative Commons licence, unless indicated otherwise in a credit line to the material. If material is not included in the article's Creative Commons licence and your intended use is not permitted by statutory regulation or exceeds the permitted use, you will need to obtain permission directly from the copyright holder. To view a copy of this licence, visit http://creativecommons.org/licenses/by/4.0/.

\section{Literatuur}

1. Rijksinstituut voor Volksgezondheid en Milieu. Volksgezondheid en zorg. 2018. www.volksgezondheidenzorg. info. Geraadpleegd op 3 december 2018.

2. Gezondheidsraad. Beweegrichtlijnen 2017. Publicatienummer 2017/08. Den Haag: Gezondheidsraad; 2017.

3. Centraal Bureau voor de Statistiek/Rijksinstituut voor Volksgezondheid en Milieu. Gezondheidsenquête (GE)/ Leefstijlmonitor (LSM). Bilthoven: RIVM;2017. 2014-2017.

4. Minister van Volksgezondheid, Welzijn en Sport. Kamerbrief. Sport \& bewegen en gezondheidszorg. Den Haag: Ministerie van VolksgezondheidWelzijn en Sport; 2016.

5. Minister van Volksgezondheid, Welzijn en Sport. Kamerbrief. Preventie in het zorgstelsel: van goede bedoelingen naar het in de praktijk ontwikkelen van resultaten. Den Haag: Ministerie van Volksgezondheid Welzijn en Sport; 2016.

6. Ministerie van Volksgezondheid Welzijn en Sport. Gezond zijn, gezond blijven. Een visie op gezondheid en preventie. Den Haag: Ministerie van Volksgezondheid Welzijn en Sport; 2007.

7. Berg M van den, Post N, Hamberg-van Reenen H, Baan C, Schoemaker C. Preventie in de zorg. Bilthoven: RIVM;2013.

8. Leemrijse CJ, Veenhof C, Bakker DH de. Kennisvraag: zorg en sport bewegen in de buurt. Utrecht: NIVEL; 2013.

9. Leemrijse CJ, Bakker DH de, Ooms L, Veenhof C. Collaboration of general practitioners and exercise providers in promotion of physical activity: a written survey among general practitioners. BMCFam Pract. 2015;16:96.

10. Noordman J, Verhaak P, Dulmen S van. Discussing patient's lifestyle choices in the consulting room: analysis of GPpatient consultations between 1975 and 2008. BMC Fam Pract. 2010;11(1):87.

11. Loket Gezond Leven. Beweegkuur. Bilthoven: RIVM; 2018.

12. Ministerie van Volksgezondheid Welzijn en Sport. Meer ruimte voor preventie in basispakket zorgverzekering. Den Haag: Ministerie van Volksgezondheid Welzijn en Sport; 2018.

13. NGH, LHV, VP Huisartsen, InEen. Toekomst Huisartsenzorg. Kerntaken in de praktijk. Utrecht: NHG;2019.

14. Bouma AJ, Wilgen P van, Baarveld F, Lemmink KAPM, Diercks RL, Dijkstra A. A cross-sectional analysis of motivation and decision making in referrals to lifestyle interventions by primary care general practitioners: a call for guidance. Am J Lifestyle Med. 2017;13(3):301-11.

15. Schurink-van'tKloosterT, LoyenA, Proper K. Meerbewegen: doorverwijzing naar activiteiten door eerstelijnszorgverleners. 2019 RIVM-briefrapport. Bilthoven: RIVM;2019.

16. Leenaars K. The Care Sport Connector in the Netherlands. Wageningen: Wageningen University; 2017.

17. Jonge M de, Singh AS, Elling A. Uit de zorg, in beweging. Utrecht: Mulier Instituut; 2019. 